\title{
Desafios do português brasileiro como língua adicional para a cidadania global
}

\author{
Isabel Cristina Michelan de Azevedo ${ }^{1}$ \\ Raquel Meister Ko. Freitag ${ }^{2}$ \\ Ricardo Nascimento Abreu ${ }^{3}$ \\ Departamento de Letras Vernáculas, Universidade Federal de Sergipe, SE, Brasil
}

Resumo: O objetivo deste artigo é discutir os desafios de ensinar português como língua adicional quando se quer desenvolver a consciência crítica intercultural e a cidadania linguística. Assim, após a retomada de conceitos norteadores dessa discussão, demarcam-se algumas lutas simbólicas que o português, na variedade brasileira, enfrenta, e, por meio de uma metodologia documental, evidenciam-se alguns entraves decorrentes da ausência de políticas estatais consolidadas para o fortalecimento do Brasil como referência no acolhimento de diferentes variedades, como a sub-representação e a estereotipia. Os resultados da análise dos dois livros didáticos, produzidos em perspectiva intercultural, indicam que os desafios para a materialização de um projeto de cidadania linguística estão associados à falta de sensibilidade local, regional, nacional e global, que estão parcialmente presentes em ambos os livros, e aos conhecimentos limitados acerca da cidadania global, por isso pouco contribuem com a difusão da diversidade linguística brasileira, que permanece negligenciada em cada um deles.

Palavras-chave: Cidadania linguística; Português brasileiro; Língua adicional; Estereotipia.

Title: Brazilian Portuguese challenges as additional language for global citizenship

Abstract: The purpose of this article is to discuss the challenges of teaching Portuguese as an additional language when one aims to develop critical intercultural awareness and linguistic citizenship. Thus, after the resumption of guiding concepts in this discussion, some symbolic struggles are demarcated that the Portuguese language, in the Brazilian variety, faces and, through a documentary methodology, some obstacles are evidenced due to the absence of consolidated state policies for the strengthening of Brazil as a reference in welcoming different varieties, such as under-representation and stereotyping. The results of the analysis of two textbooks, produced in an intercultural perspective, indicate that the challenges for the materialization of a linguistic citizenship project are associated with the lack of local, regional, national and global sensitivity that are partly present in both books,

1 Doutora em Letras (USP), professora na UFS. Orcid: https://orcid.org/0000-0002-5293-0168. E-mail: icmazevedo@hotmail.com

2 Doutora em Linguística (UFSC), Professora na UFS. Orcid: https://orcid.org/0000-0002-4972-4320. E-mail: rkofreitag@uol.com.br

${ }^{3}$ Doutor em Letras e Linguística (UFBA), Professor na UFS. Orcid: https://orcid.org/0000-0003-3829-7973. Email: tennascimento@gmail.com 
and the limited knowledge about global citizenship that is why they contribute little to the spread of Brazilian linguistic diversity, which remains neglected in each of them.

Keywords: Linguistic citizenship; Brazilian Portuguese; Additional language; Stereotypes.

\section{Introdução}

A noção de cidadania, tomada por uma perspectiva histórica, pode se constituir como ferramenta reveladora das organizações sociais e políticas dos povos ao longo dos tempos, das formas pelas quais as sociedades lidam com as desigualdades e das violências sofridas pelos oprimidos na luta pela conquista de direitos, de modo que é possível acompanhar a história da humanidade e dos direitos humanos por meio dos mais distintos paradigmas conceituais vinculados ao significado do termo "cidadania".

Para tanto, é necessário construir um modelo de leitura do mundo que leve à reformulação do paradigma de cidadania, pautado por um viés que se fundamenta, ao menos teoricamente, na necessidade de garantir o exercício de direitos e de definir obrigações visando ao desenvolvimento das nações por meio do reconhecimento das diferenças, da solidariedade entre os povos e do compromisso com valores universais a exemplo da dignidade, da igualdade, do respeito e da justiça social. Confronta-se, então, o desafio de alcançar o que tem sido denominado de "cidadania global" (UNESCO, 2016).

A construção da cidadania perpassa pela língua, e a linguística na contemporaneidade tem sido pensada, tomada e perseguida a partir do paradigma da cidadania global, sendo esse um dos principais desafios da sociedade do século XXI. Sob essa perspectiva, visto que as formas sancionadas e institucionalizadas por cada Estado para considerar os direitos e as necessidades de grupos sociais específicos podem restringir as formas pelas quais uma parcela dos cidadãos pode expressar sua voz e lutar por seus direitos (WILLIAMS; STROUD, 2015).

Em particular, no âmbito educacional, nota-se que os desafios de ensinar português, especialmente, como língua adicional, podem auxiliar o entendimento de como os usos da língua estão ligados a discursos públicos, a determinados modos de produzir concepções e ideias sobre cada realidade, às formas de interação pela linguagem, como foi observado por Schlatter e Garcez (2018), daí a relevância de se buscar estabelecer o diálogo intercultural que, segundo o Relatório Mundial da UNESCO (2009), pode se constituir como elo voltado a fortalecer a diversidade das expressões culturais, mediante processos de apoio e reforço das autonomias.

Contudo, o diálogo intercultural não pode resolver todos os conflitos políticos, econômicos e sociais, por isso é essencial ter consciência e estar informado das implicações da diversidade cultural na elaboração das políticas públicas e das políticas linguísticas que dependem da cultura e das ideias que teorizam a cidadania como uma instituição em fluxo, embutida em lutas sociais e políticas (ISIN, 2009). Nesse sentido, parece ser indispensável no ensino de português como língua adicional, na perspectiva da cidadania global, desenvolver a consciência crítica intercultural (JESUS, 2016; FINARDI; GUIMARÃES, 2017; SANTOS; FROSSARD, 2018), o que significa que o ensino da língua não pode estar limitado às 
capacidades críticas para contrapor pontos de vista unilaterais (UNESCO, 2009) e favorecer a compreensão do conjunto das estruturas linguísticas que podem limitar as relações entre culturas ou fomentar o repensar das relações subjacentes a práticas particulares de linguagem, como propõe a cidadania linguística (WILLIAMS; STROUD, 2015).

Assim, neste texto, são exploradas as lutas simbólicas do português como língua adicional, na variedade brasileira, para observar os entraves decorrentes da ausência de políticas estatais consolidadas para o fortalecimento do Brasil como referência, além de demarcar problemas no modo como este ensino tem sido implementado, como a subrepresentação e a estereotipia, uma vez que esses problemas que se configuram como desafios para a materialização de um projeto de cidadania linguística.

Primeiramente, são revistas ideias relativas ao conceito de cidadania global como base para a configuração do conceito de cidadania linguística global. Em seguida, discutem-se as relações de apagamento das diversidades que uma língua hegemônica provoca, bem como os processos que levam à estereotipia das línguas. Na última parte, apresenta-se uma discussão em torno do ensino de português como língua adicional, considerando tanto os documentos basilares para o planejamento de práticas docentes quanto a análise de dois livros didáticos produzidos em perspectiva intercultural. Tais aspectos são decorrentes da ausência de políticas linguísticas para o ensino de português como língua adicional que considerem o Brasil como referência, o que restringe a materialização de um projeto de cidadania linguística.

\section{A noção de cidadania global: um conceito emergente?}

Cidadania é um conceito que passou por transformações no decorrer dos tempos, sendo possível identificar um período de "pré-história da cidadania", envolta em todas as representações que essa noção remontava na antiguidade entre hebreus, gregos e romanos; nos primórdios da era cristã e durante o período renascentista europeu (PINSKY; PINSKY, 2012). Esse período é marcado por elementos que serviram de fonte germinal para a consolidação da ideia de cidadania no Ocidente, desenvolvida de forma mais pujante após os movimentos burgueses que culminaram com as revoluções inglesa, americana e francesa. A separação dos poderes, as limitações dos Estados em contraposição aos direitos individuais e coletivos, a liberdade, igualdade e fraternidade são verdadeiros marcos indissociáveis da odisseia humana na sua luta por cidadania no mundo (PINSKY; PINSKY, 2012).

Durante o século XX, o final da Segunda Guerra Mundial e a reorganização do mundo entre o antagonismo dos sistemas capitalista e socialista trouxeram novos elementos ao debate e, apesar das tensões políticas que ganharam relevo no período da guerra fria, a humanidade conseguiu avançar em pautas importantes e decisivas para que a noção de cidadania global pudesse ser viabilizada na nossa contemporaneidade. A criação do sistema global e dos sistemas regionais de proteção aos direitos humanos, os avanços na implementação dos direitos sociais, a defesa de grupos vulneráveis (crianças, mulheres e idosos), a pauta das minorias e do multiculturalismo, a defesa do meio ambiente e, mais 
recentemente, os múltiplos efeitos da globalização (tecnológicos, econômicos, culturais e políticos) conduziram, segundo Pinsky e Pinsky (2012), o debate sobre a necessidade de a extensão do exercício da cidadania extrapolar os limites políticos, territoriais e ideológicos das nações e dos nacionalismos e abordar um contexto mais amplo, no qual os direitos e obrigações dos indivíduos e dos grupos devem estar intimamente compromissados não apenas com as questões locais e regionais, mas também com a ideia de responsabilidade global.

A noção de responsabilidade global pressupõe a solidariedade entre os povos, assumida como único caminho para o desenvolvimento futuro do globo (PIOVESAN; SOARES, 2010; SEN, 2010; ANJOS FILHO, 2013), sob a premissa de que seria insustentável para as nações mais ricas manterem os seus status quo às custas da miséria do restante do planeta, "uma vez que a intensidade das necessidades econômicas aumenta - e não diminui - a urgência das liberdades políticas" (SEN, 2010, p. 195). Essas pautas se alinham ao que vem se convencionando chamar de "novos direitos" (WOLKMER; LEITE, 2012). Especificamente em relação à proteção global das minorias, emerge uma nova gramática moral dos conflitos sociais em torno das lutas por reconhecimento (HONNETH, 2011). Ou seja: como todos os confrontos sociais e todas as formas de conflito seriam constituídos de acordo com um mesmo modelo de luta por reconhecimento, todo ato coletivo de resistência e rebelião seria atribuído, segundo sua origem, a um quadro invariante de experiências morais, dentro do qual "a realidade social é interpretada conforme uma gramática historicamente cambiante de reconhecimento e de desrespeito" (HONNETH, 2011, p. 260). Nesse processo, então, a gramática moral das lutas sociais precisa confrontar as bases conceituais utilitaristas e a pesquisa meramente histórica dos movimentos políticos que, por longo tempo, serviram de modelo referencial para a persecução coletiva de interesses de culturas desprestigiadas.

Essas lutas, que vêm sendo empreendidas mais recentemente, deram força para que os debates sobre o multiculturalismo (TAYLOR, 1994) e as teorias pós-coloniais e decoloniais (SANTOS; MENESES, 2010) pudessem permear a forma como se pode interpretar o(s) local(is) de cada um no mundo.

Alinhada a essas condições de existência, desde 2012, a Organização das Nações Unidas para Educação, Ciência e Cultura (Unesco) passou a definir a cidadania global como o "sentimento de pertencer a uma comunidade mais ampla e a uma humanidade comum. Ela enfatiza a interdependência e a interconexão política, econômica, social e cultural entre os níveis local, nacional e global" (UNESCO, 2015, p. 15), a fim de promover a cidadania global como uma das três prioridades do órgão no campo da educação.

Uma das diretrizes da cidadania global é a formação para "reconhecer e apreciar as diferenças e identidades múltiplas, por exemplo, em termos de cultura, língua, religião, gênero e nossa humanidade comum, além de desenvolver habilidades para viver em um mundo com cada vez mais diversidade" (UNESCO, 2015, p. 16). Uma formação deste tipo requer o desenvolvimento de três atributos: "ser informado e capaz de pensar criticamente; estar socialmente conectado e ter respeito pela diversidade; ser eticamente responsável e 
engajado" (UNESCO, 2015, p. 23). É nesse cenário que as línguas e a diversidade linguística ganham protagonismo como instrumentos fundamentais à formação e à consolidação do cidadão global.

Retomando o cenário do pós-guerra, a questão da proteção da diversidade linguística e das minorias linguísticas que também emergem nesse período começa a permear, ainda que de forma desigual, as preocupações dos Estados nacionais contemporâneos, que já não podem mais ficar alheios ao fato da existência do campo do direito linguístico, que visa fundamentalmente a desenvolver instrumentos de tutela protetiva das línguas e dos direitos e deveres dos seus falantes.

Pensar o direito linguístico a partir das suas relações jurídico-linguísticas e das relações com outros campos do conhecimento - a exemplo da sociologia, da antropologia e da ciência política - reforça que não é mais possível conceber as noções de democracia, direitos humanos e justiça social desassociados do constructo do exercício da cidadania linguística (FILIPE, 2009; NZAU; SARDINHA, 2009; GIORDAN; AGRESTI, 2009; ABREU, 2016; SIGALESGONÇALVES, 2018), uma vez que a existência de direitos e deveres linguísticos engajados com as realidades locais, regionais, nacionais e globais é condição sine qua non para a concretização de direitos fundamentais, a exemplo da liberdade, da igualdade e da dignidade humana.

\section{Desafios para a promoção de uma cidadania linguística global em um contexto de línguas hegemônicas}

A noção de cidadania global não é uníssona no ambiente acadêmico - há mesmo as correntes que questionam a viabilidade de uma agenda de cidadania global (cf. DAVIES, 2006; SCHLTZ, 2007) -, pois, em algumas análises, o termo tem sido substituído, não de forma sinonímica, por expressões que buscam agregar novos elementos alegadamente ausentes no conceito postulado pela Unesco. Assim, há registros que mais se aproximam da terminologia da Unesco, tais quais "cidadania sem fronteiras" e "cidadania além do Estado-nação", e outros que buscam dar maior amplitude ao conceito, ou, ainda, registrar uma relação de accountability entre os indivíduos e o planeta, a exemplo dos termos "cosmopolitanismo" ou "cidadania planetária", respectivamente.

Ainda no entendimento da Unesco, não obstante as divergências conceituais, há um traço comum que estabelece um liame possível entre as diferentes abordagens terminológicas e que se configura como a espinha dorsal de pensamento moderno acerca do caráter global que a cidadania pode assumir: a desvinculação administrativa e jurídica em relação aos países em detrimento de uma condição supralegal de pertencimento ao contexto global.

Apesar de diferenças de interpretação, existe um entendimento comum de que cidadania global não implica uma situação legal. Refere-se mais a um sentimento de pertencer a uma comunidade mais ampla e à humanidade comum, bem como de promover um "olhar global", que vincula o local ao global e o nacional ao internacional. Também é um modo de entender, agir e se relacionar com os outros 
e com o meio ambiente no espaço e no tempo, com base em valores universais, por meio do respeito à diversidade e ao pluralismo. Nesse contexto, a vida de cada indivíduo tem implicações em decisões cotidianas que conectam o global com o local, e vice-versa (UNESCO, 2015, p. 14).

A viabilidade do caráter universal e supranacional com que a ideia da cidadania global pretende se constituir é fruto dessa nova ordem mundial, em que o antes intocável princípio da soberania absoluta dos Estados passou a ser mitigado e relativizado, a partir do momento no qual tais nações concordam em permitir que elaborações em matéria de direitos humanos, produzidas no âmbito das Nações Unidas, possam influenciar os modos por meio dos quais os países conduzem as suas políticas internas, em especial naquilo que diz respeito aos direitos das minorias e dos grupos vulneráveis. E é desse contexto que emergem tanto a noção de direito linguístico quanto a de cidadania linguística, configurada para superar algumas visões discriminatórias existentes dentro das pesquisas relativas aos direitos, como defende Stroud (2001).

Discutir a noção de cidadania linguística no contexto da cidadania global implica ampliar suas limitações visando a transformar a desvalorização identitária de uma coletividade estigmatizada, a fim de promover condições de vida mais equitativas (STROUD, 2001) e, para outros autores, reconhecer os avanços e as vitórias que o direito linguístico obteve nas últimas sete décadas que marcaram a transição entre os séculos XX e XXI, segundo Abreu (2016).

A inclusão de um conjunto significativo dos direitos linguísticos em espécie no rol dos direitos humanos, a criação dos sistemas global e regionais de proteção desses direitos, a formulação de instrumentos de direito internacional dos direitos humanos com foco na proteção das minorias linguísticas, o ativismo político-linguístico das comunidades linguisticamente minoritárias e os processos de patrimonialização da diversidade linguística são algumas destas conquistas (ABREU, 2016).

Apesar disso, é importante reconhecer que a efetivação de uma cultura amparada na cidadania linguística global também encontra resistências de naturezas múltiplas e de várias origens, como os discursos formulados a partir de tradições inventadas e - tanto as construídas e formalmente institucionalizadas em determinado tempo histórico quanto o conjunto de práticas, normalmente reguladas por regras tácitas ou abertamente aceitas de natureza ritual ou simbólica (HOBSBAWM, 1984) - que geram assimetrias de poder entre as línguas.

Também é possível constatar que as ações e omissões dos Estados nacionais resultam no desaparecimento de culturas linguísticas inteiras (PREUSS; ALVARES, 2014), que as políticas de constitucionalização de línguas oficiais podem não seguir devidamente as políticas de nacionalização das demais línguas do território (SANTOS, 2009) e que nas grandes fonias em torno de línguas hegemônicas (OLIVEIRA, 2013; MARTINS, 2018) há disputas entre países pelo monopólio dos seus registros linguísticos nos processos de ensino de línguas estrangeiras. Esses são alguns dos conflitos que se revelam nesse mercado linguístico simbólico, nos termos de Bourdieu (2008), no qual as línguas possuem pesos, valores e representações que se 
colocam como verdadeiros obstáculos a um exitoso processo de formação de cidadãos globais.

Particularmente, no escopo da lusofonia, dois macroprocessos de fortalecimento político da língua portuguesa, que, se conduzidos de forma desarticulada, podem exercer direta e indiretamente ações mitigantes sobre a materialização da cidadania linguística global precisam ser observados no conjunto de países que executam procedimentos domésticos e internacionais de regulação administrativa baseados no português (MARTINS, 2011).

O primeiro macroprocesso é a constitucionalização da língua portuguesa como língua oficial, mesmo em países onde não é falada pela maioria da população. O segundo macroprocesso é a própria formação do bloco da lusofonia, que posiciona a língua portuguesa lado a lado de outras línguas transcontinentais, dotando-Ihe de capital político e econômico cujo efeito colateral é a catalisação da vulnerabilidade das línguas minoritárias.

Um dos primeiros efeitos em massa produzidos pela ONU, no âmbito dos seus países membros, não diz respeito à efetiva proteção das minorias linguísticas em seus territórios, nos termos da Declaração Universal dos Direitos Humanos (RUSSELL; COHN, 2012; ABREU, 2016; 2019), pois ocorreu, de fato, a emergência de inúmeros processos de constitucionalização de línguas oficiais, especialmente após a aprovação do Pacto Internacional dos Direitos Civis e Políticos e do Pacto Internacional sobre Direitos Econômicos, Sociais e Culturais, ambos de 1966.

\begin{abstract}
A inserção maciça de línguas oficiais nos textos constitucionais da maioria dos países do globo terrestre tornou mais latente, aos olhos do mundo, questões de políticas de línguas atinentes às mais variadas espécies de conflitos linguísticos em seus territórios, tais quais aqueles que envolvem os processos de nacionalização das línguas não-oficiais; as minorias linguísticas e os seus direitos (indígenas, imigrantes, comunidades surdas); a preservação da diversidade linguística como um patrimônio cultural do mundo; os processos educacionais em contextos plurilíngues; o ensino de línguas estrangeiras, entre outros (ABREU, 2019, p. 51).
\end{abstract}

O Brasil, por exemplo, em toda a sua história constitucional, que se inicia no século XIX, nunca havia constitucionalizado uma língua oficial antes da promulgação da atual Constituição da República, em 1988. Influenciado pela Constituição Portuguesa de 1976, o Estado brasileiro vincula a sua língua oficial aos direitos da nacionalidade, à bandeira, ao hino, às armas e ao selo nacionais, sinalizando o entendimento de que as questões linguísticas de proteção do Estado precedem àquelas que visam a proteger os indivíduos e os grupos (SANTOS, 2009).

A constitucionalização do português como língua oficial do Brasil, aliada ao inacabado processo de nacionalização de línguas indígenas e à inexistência de estatutos jurídicos para as demais línguas brasileiras, especialmente as que se originaram de processos migratórios ocorridos na transição dos séculos XIX e XX, criou um ambiente de profunda e polarizada assimetria política que colocou o português em uma situação de hegemonia interna em relação às demais línguas constitutivas da realidade multilíngue nacional (PREUSS; ALVARES, 2014). 
Aliado a isso, os processos de regulação internacionais também podem afetar diretamente o desenvolvimento de um ideal em torno da concretização de uma cidadania linguística global. Isso porque as disputas que se estabelecem entre as grandes fonias do mundo, tais quais a francofonia, a anglofonia e a lusofonia (OLIVEIRA, 2013; MARTINS, 2018), bem como o próprio processo de formação desses conglomerados linguísticos fomentado pelas nações, potencializa a situação de vulnerabilidade das minorias linguísticas internas e, ainda, de forma concomitante, contribui para a geração de disputas entre os países pelo monopólio de ter a sua variedade erigida ao patamar de registro a ser utilizado nos processos de ensino de língua estrangeira. Essas questões têm impacto na agenda do português como língua adicional (PLA) - conceito que acompanha o esforço inclusivo de compreender as relações de "acréscimo" ou "adição" de línguas em uso em uma sociedade (cf. JUDD; TAN; WALBERG, 2001) -, bem como na consolidação de uma cidadania global, no escopo dos países de língua portuguesa, uma vez que o pluralismo no ensino de línguas abre espaço para uma maior participação de diferentes agentes nos espaços educativos.

\section{Português como língua hegemônica: diversidade e estereotipia}

Quando se trata do português como língua adicional, pode-se pensar no ensino dessa língua para falantes de outras línguas que não o português, seja dentro de um Estado nacional, como no caso de Cabo Verde, Angola ou Moçambique, países da Comunidade dos Países de Língua Portuguesa (CPLP), seja como língua para outros Estados/territórios, em função de demandas comerciais ou artístico-culturais. Tanto no primeiro como no segundo caso, existe uma disputa entre qual variedade do português assume o papel de referência como língua hegemônica.

A construção de uma unidade política nacional por meio de uma língua, como é o caso do português em Angola, tem consequências graves para a população; por exemplo, o acesso a serviços de saúde em Angola é limitado ao seu domínio linguístico, dado que a maior parte dos médicos não tem domínio das línguas autóctones (TIMBANE; BERNARDO, 2020). Este é um dos efeitos da hegemonia para os falantes das línguas: desvalorização e assimetria entre as variedades nacionais, juntamente ao desconhecimento da natureza multilíngue e heterogênea dos Estados (RONCARATI; SILVA; PONSO, 2012). Dada a expressividade da parcela da população excluída do acesso aos serviços básicos para o exercício da cidadania, e considerando a construção de uma tradição de lusofonia (SANTOS, 2015), existe uma disputa sobre qual é a variedade de língua portuguesa que será tomada como referência para ser representada nos materiais didáticos, nas comunicações oficiais, ou na difusão da ciência, da tecnologia e da arte em ações de ensino do português como língua adicional.

Nesse embate, o português europeu e o português brasileiro assumem o protagonismo em função de sua visibilidade e representatividade, que se traduz no estatuto do português padrão (standard), sustentado "[n]a crença de que têm normas mais rígidas, maior uniformidade na escrita, melhores recursos para exportar sua variedade em programas 
de ensino de língua, bem como para publicar gramáticas, dicionários e livros didáticos" (PONSO, 2008, p. 149). As relações sociopolíticas estabelecidas no âmbito da CPLP revelam a competição entre as variedades do português, europeu e brasileiro, em disputa pelo papel de referência (MIYAMOTO, 2009).

O português ainda não é uma língua oficial de trabalho das Nações Unidas, como o são inglês, francês, espanhol, árabe, russo e mandarim. Tratativas para a sua inclusão se intensificaram a partir de 2019, com a adesão da Unesco às comemorações do dia da Língua Portuguesa. Quando oficializada como língua de trabalho, qual será a variedade nacional que será utilizada como padrão de referência? A portuguesa ou a brasileira?

As diferenças entre as variedades da mesma língua no cenário da lusofonia são amplamente descritas pela perspectiva sociolinguística, que evidencia duas variedades com características bem definidas, especialmente a partir do contraste do português brasileiro (FREITAG, 2016). Mas, muito mais do que diferenças descritas, há impactos em termos comerciais: plataformas de serviço de correio eletrônico e comunicação, como Gmail, Yahoo! Mail, Hotmail e Skype, utilizam recursos linguísticos, especialmente no que se refere aos pronomes, que são específicos para o mercado brasileiro e para o mercado português (MANOLE, 2013). Quando elevada à esfera política, a disputa por uma variedade hegemônica de referência para o português, se por um lado, neutraliza as demais variedades e acentua as assimetrias entre as variedades da construção da lusofonia (RONCARATI; SILVA; PONSO, 2012), por outro, indica que a conquista da hegemonia é construída e mantida por meio de estereótipos.

A estereotipia é o processo pelo qual estruturas cognitivas que contêm nossos conhecimentos e expectativas, e determinam nossos juízos e avaliações sobre os grupos humanos e seus membros (HAMILTON; TROLIER, 1986), que levam à construção de um conjunto de características associadas a um rótulo ou etiqueta. São generalizações ou simplificações, que, em princípio, possibilitam a automatização de processos cognitivos, com menor tempo de resposta e maior disponibilidade cognitiva, garantindo a sobrevivência. Mas, tal como propõe Tajfel (1981), estas generalizações, quando são compartilhadas entre um grupo ou entidade coletiva, podem ativar relações de hierarquia que levam à discriminação e ao preconceito, inclusive linguístico (FREITAG et al., 2020).

A estereotipia atua no processo de construção da hegemonia da variedade da língua que alça o status de referência. Pode-se dizer que a construção de estereótipos sobre as línguas (ou as variedades de português) não só é favorecida, mas como é estimulada, quando se considera que a formação para a cidadania global deve possibilitar "reconhecer e apreciar as diferenças e identidades múltiplas, por exemplo, em termos de cultura, língua, religião, gênero e nossa humanidade comum, além de desenvolver habilidades para viver em um mundo com cada vez mais diversidade" (UNESCO, 2015, p. 16). Como fazer para "ensinar cultura" é uma das questões latentes na agenda de pesquisa de ensino de línguas estrangeiras ou adicionais, como questiona Kramsch (2017): 
O que é cultura? Qual é a sua relação com a língua? Qual cultura deve ser ensinada? A cultura de quem? Qual o papel da cultura do aluno no processo de aquisição de conhecimento da cultura-alvo? Como podemos evitar a essencialização das culturas e o ensino de estereótipos culturais? Ainda, como podemos desenvolver, nos alunos, uma competência intercultural em que a sua cultura e a cultura-alvo não sejam tratadas de forma injusta, mas que sejam percebidas como mediadores culturais em um mundo globalizado? (KRAMSCH, 2017, p. 134)

Propostas de ensino de português como língua adicional que considerem aspectos da tradição artístico cultural têm sido aventadas e enfrentam sempre o desafio de evitar a construção de estereótipos culturais que possam prejudicar a construção de uma cidadania global. Um exemplo de esforço no sentido de recuperar características próprias de uma cultura-alvo encontra-se em Alfaiate (2018), que considera a tradição de Portugal em azulejos como uma marca identitária para o ensino da língua, com a inclusão de peças de azulejaria para a integração da dimensão intercultural. Outro, identificado no Brasil, propõe pela noção de "mineiridade" a articulação de conteúdos global e localmente para promover o contato entre diferentes culturas ao ensinar português como língua de acolhimento (COSTA; SILVA, 2019).

Ao eleger uma variedade e não outra como língua de referência, as propostas de ensino também elegem uma cultura e não outra, na medida em que nunca se esgotarão as dimensões culturais de uma nação. Essa é uma consequência da hegemonia das línguas, bem como um empecilho a uma formação para a cidadania global: "a educação para a cidadania global dificilmente se concretizará com as abordagens habituais folclorizantes baseadas nos conhecimentos factuais ligados a festas e comidas" (SEQUEIRA, 2018, p. 134).

Se Brasil e Portugal apresentam diferenças linguísticas a tal ponto de se caracterizarem como línguas distintas quanto à sua gramática, com impactos inclusive econômicos, dentro do Brasil - um país com dimensões continentais que vive o mito do monolinguismo, o país onde todos falam português - também existem diferenças, tanto linguísticas (variedades do português brasileiro) quanto de representações sociais e de valores associados a essas representações (identitárias).

As contribuições da Sociolinguística para a identificação de valores identitários regionais a traços linguísticos variáveis e como estes se manifestam nas representações regionais, como o português paulista, português carioca, português sergipano, rio-grandense, etc., têm permitido a ampliação da compreensão do que é o rótulo "português brasileiro" (FREITAG et al., 2015; 2016), desfazendo o mito da unidade, o que inclui não só a descrição das variedades do ponto de vista da sua gramática (funcionamento linguístico), mas também o julgamento do valor linguístico que sustenta as atitudes e a estereotipia.

Nesse sentido, tais contribuições apoiam o ensino de português como língua adicional na medida em que a noção de heterogeneidade sistemática e de mudança, como sugerem Ferreira e Antunes (2018), complementa os estudos de percepção, por orientar como perceber as crenças e atitudes dos falantes em relação à língua e em relação aos valores associados a essa língua, para possibilitar um ensino dissociado da construção de estereótipos 
culturais, especialmente em relação ao Brasil. É preciso, como sugerem Andrade e Martins (2018) pensar a formação de professores para lidar com a realidade multilíngue e diversificada dialetalmente na construção da cidadania global. Na perspectiva da cidadania global, é preciso reconhecer o direito à diversidade linguística, tanto em termos de línguas dentro de um território e suas relações, como em Angola (NZAU; SARDINHA, 2009), como a diversidade de variedades e dialetos (GIORDAN; AGRESTI, 2009).

A estereotipia associada ao preconceito é um risco que se corre quando se quer inserir a dimensão cultural em materiais didáticos, podendo cair no nível do folclórico ou do estigma. Recentemente, um material didático para ensino de português como língua adicional ganhou espaço nas manchetes por "frases preconceituosas" e por mencionar o "MST" (Movimento dos Sem Terra) com valoração negativa. O material, intitulado "Só verbos", trabalhava conteúdos gramaticais do português (Figura 1) e, segundo a reportagem publicada no jornal O Globo, de 20 de junho de 2020, seria um material oficial do Itamaraty, sendo veiculado pela Rede Brasil Cultural, da Divisão de Promoção da Língua Portuguesa do Ministério das Relações Exteriores, que tem como objetivo promover a língua e a cultura brasileira no exterior.

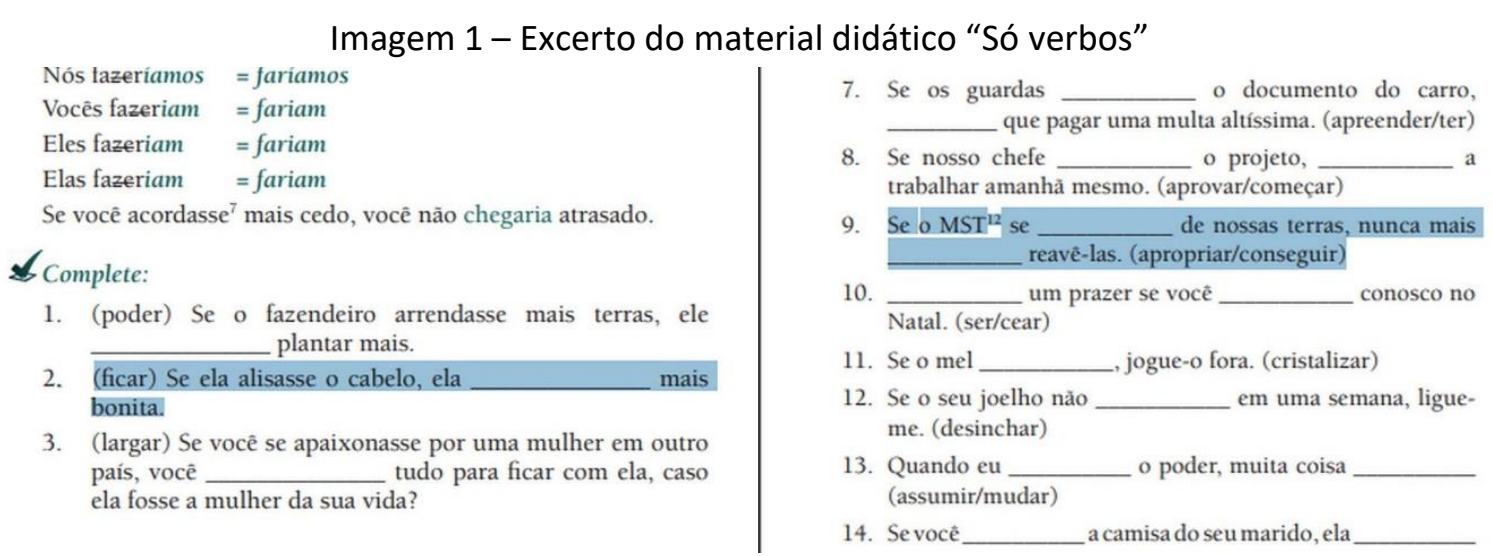

Fonte: O Globo (2020, s. p.).

A Sociedade Internacional de Português-Língua Estrangeira (SIPLE) divulgou nota dando voz à autora do material, que esclareceu o contexto temporal em que foi produzido (2013), e esclarecendo que "o Ministério das Relações Exteriores não obriga o uso desse ou de qualquer material didático em nenhum de seus Centros Culturais" (SIPLE, 2020, p. 4). No entanto, por ser um material que, até o momento da reportagem, estava disponível no site da instituição, constitui-se como um caso que registra a falta de uma formação sociolinguística para o professor de português como língua adicional, o que prejudica a difusão da variedade brasileira como referência do português desvinculada da estereotipia e a consolidação de um material favorável à construção de uma cidadania linguística global. A disputa entre as variedades para o status de língua de referência é marcada por uma trajetória em que aspectos sociolinguísticos de uma variedade são amplamente difundidos como o padrão, o que é resultado de uma política de produção de material didático e difusão de língua. 
A situação torna-se ainda mais grave quando se constata que para aqueles que querem ensinar uma variante específica do português faltam materiais de referência que considerem as especificidades do português brasileiro tanto em termos linguísticos quanto interculturais, fazendo com que se procure apoio em documentos que não levam em conta as condições sociais próprias dos que habitam territórios ao sul do Equador ou em livros didáticos que condensam uma visão de nação associada a de estereótipos.

Assumindo que "[...] educação para a cidadania global envolve o conhecimento dos factos, da história e das religiões mas mais do que isso, exige capacidades de organização e cooperação e também o pensamento crítico sobre princípios económicos, o domínio de línguas estrangeiras e a boa comunicação [...]" (SEQUEIRA, 2018, p. 134), é necessário refletir sobre como as políticas linguísticas vêm sendo organizadas no Brasil, a fim de identificar as perspectivas de cidadania linguística que estão sendo oferecidas aos brasileiros, e, ao mesmo tempo, como esta cidadania linguística se reflete em termos da construção de uma cidadania global, com o português brasileiro como língua adicional (PLA).

\section{O ensino do português brasileiro como PLA}

A implementação de políticas linguísticas no Brasil voltadas ao ensino de português, em alinhamento à educação para a cidadania global nos termos da proposta da Unesco (2015) requer a identificação de ações de políticas linguísticas que têm sido realizadas no sentido de difundir o português brasileiro em âmbito internacional; e a reflexão sobre o papel dos livros didáticos na configuração de estereotipias.

\section{Políticas linguísticas para a difusão do português brasileiro}

Compreender o diálogo intercultural - que sensibiliza os sujeitos a identificar as diversas formas pelas quais as culturas se relacionam umas com as outras e pode gerar uma maior consciência dos valores que partilham e dos seus objetivos comuns (UNESCO, 2009) -, não apenas como um diálogo entre representantes de determinadas culturas, pois ressalta os valores e as virtudes de cada uma delas, torna-se essencial para viabilizar a construção de uma crítica interna e para apoiar o trabalho de críticos e integrantes uma "periferia" cultural voltados a realizar um movimento em prol de um diálogo intercultural Sul-Sul (DUSELL, 2016). Defende-se nesta discussão que a ausência dessa crítica dificulta realizar uma interpretação histórico-mundial mais ampla que possibilite compreender o lugar do português brasileiro na cidadania global.

Verifica-se, no âmbito internacional, que o português brasileiro convive com o português que também é língua oficial em outros países e concorre pela prevalência frente ao português europeu no que tange ao padrão que serve de referência para o ensino de línguas adicionais. Nessa competição pela hegemonia, cada país estabelece políticas linguísticas e fortalece as instituições que podem colaborar com a afirmação de uma variedade sobre outra. 
Como o termo política linguística engloba tanto as decisões tomadas no nível mais geral quanto as atividades que contribuem para implementá-las, assume um duplo papel: é uma política linguística (language policy) que define o planejamento linguístico (language planning) (SPOLSKY, 2004).

A análise das ações definidas pelo governo brasileiro nos últimos anos para impulsionar a divulgação do português brasileiro mundo afora permite identificar as medidas assumidas pelo Estado brasileiro como ações políticas de difusão do português, na variante nacional, reunidas no quadro 1.

Quadro 1 - Políticas linguísticas de incentivo à divulgação internacional do português brasileiro

\begin{tabular}{|c|c|}
\hline $\begin{array}{l}\text { PEC-G } \\
\text { Criado em } 1965\end{array}$ & $\begin{array}{l}\text { O Programa de Estudantes-Convênio de Graduação, administrado pelo MRE } \\
\text { e MEC, oferece a estudantes de países em desenvolvimento com os quais o } \\
\text { Brasil mantém acordo educacional, cultural ou científico-tecnológico a } \\
\text { oportunidade de realizar seus estudos de graduação em Instituições de } \\
\text { Ensino Superior brasileiras. }\end{array}$ \\
\hline $\begin{array}{l}\text { PEC-PG } \\
\text { Criado em } 1981\end{array}$ & $\begin{array}{l}\text { O Programa de Estudantes-Convênio de Pós-Graduação, administrado por } \\
\text { três órgãos (MRE, CAPES, MCTI), oferece bolsas de estudo para estudantes } \\
\text { de países em desenvolvimento com os quais o Brasil possui acordo de } \\
\text { cooperação cultural e/ou educacional, para formação em cursos de pós- } \\
\text { graduação strictu sensu (mestrado e doutorado) em Instituições de Ensino } \\
\text { Superior brasileiras. }\end{array}$ \\
\hline $\begin{array}{l}\text { Bolsa Capes - } \\
\text { FULBRIGHT } \\
\text { Criada em } 1984\end{array}$ & $\begin{array}{l}\text { Bolsa para professor assistente de língua portuguesa nos EUA, concedida } \\
\text { pela CAPES, com base no acordo de cooperação assinado com a Comissão } \\
\text { Fulbright, que tem como objetivo incrementar o ensino de português em } \\
\text { universidades norte-americanas e estreitar as relações bilaterais entre os } \\
\text { dois países. }\end{array}$ \\
\hline $\begin{array}{l}\text { Celpe-Bras } \\
\text { Criado em } 1994\end{array}$ & $\begin{array}{l}\text { O Certificado de Proficiência em Língua Portuguesa para Estrangeiros (Celp- } \\
\text { Bras) é o exame oficial para certificar proficiência em língua portuguesa. } \\
\text { Aplicado semestralmente, no Brasil e no exterior, pelo Ministério da } \\
\text { Educação (MEC), por meio do Instituto Nacional de Estudos e Pesquisas } \\
\text { Educacionais Anísio Teixeira (Inep), em parceria com o Ministério das } \\
\text { Relações Exteriores (MRE), o certificado é conferido em quatro níveis: } \\
\text { intermediário, intermediário superior, avançado e avançado superior. }\end{array}$ \\
\hline $\begin{array}{l}\text { Programa Leitorado } \\
\text { Instituído em } 1999\end{array}$ & $\begin{array}{l}\text { Coordenado pela CAPES, em parceria com o Ministério das Relações } \\
\text { Exteriores (MRE), este programa financia seleciona professores para atuar } \\
\text { em Instituições de Ensino Superior estrangeiras, em duas frentes: promover } \\
\text { a língua portuguesa, em sua vertente brasileira, e divulgar a cultura, } \\
\text { literatura e estudos brasileiros. }\end{array}$ \\
\hline
\end{tabular}

Fonte: Elaboração dos autores.

Além dessas iniciativas, em seguimento ao Decreto n. 3.194/99, que internaliza o Protocolo de Integração Educacional para Formação de Recursos Humanos no nível de pósgraduação nas universidades dos Estados parte do Mercosul, durante aproximadamente dez anos, foram concedidas bolsas de doutorado para docentes a fim de promover o intercâmbio e a formação de docentes universitários, para que contribuam com a melhoria da qualidade 
do ensino e da pesquisa das universidades da região e o desenvolvimento sustentável dos países do Mercosul, nas diversas áreas do conhecimento, mas essa foi desativada em 2019.

Como apoio a essas ações, em 2005, foi criado o Instituto Machado de Assis (IMA), com a missão de formular e coordenar as políticas de promoção da língua portuguesa no Brasil e no mundo; induzir, catalisar e organizar a pesquisa nessa língua; ser referência para o ensino e formação de professores; promover atividades científicas e culturais, no Brasil e no mundo, visando à promoção e difusão da língua portuguesa.

Esse Instituto deveria formular e coordenar as políticas para a língua portuguesa no Brasil e no mundo em quatro eixos: difusão e ensino, documentação, pesquisa, políticas, em consonância com o Ministério das Relações Exteriores, a fim de difundir essa língua nos países não lusófonos, em colaboração com a CPLP. Contudo, na página do Ministério da Educação e Cultura não são encontradas atividades do IMA há vários anos.

Em compensação, o Instituto da Cooperação e da Língua de Portugal, Instituto Camões, gerenciado pelo Ministério dos Negócios Estrangeiros, tem representação em trinta e dois países da Europa, dezenove países da África, dez países nas Américas, dez países na Ásia e Oceania; oferece cooperação quanto ao ensino-aprendizagem do Português e bolsas de estudos; faz divulgação cultural; tem um Centro Virtual, além de disponibilizar vários serviços on-line. $O$ fato de o Instituto Camões estar subjugado a um ministério ligado às finanças do País, indica que o escopo de atuação desse instituto supera os limites dos objetivos educacionais.

Desde 1993, com a constituição da União Europeia, visando à formação de um mercado único, Portugal passou a participar de um conjunto de ações estratégicas entre as quais se destaca o Projeto de "Políticas Linguísticas para uma Europa Multilíngue e Multicultural", que possibilitou a elaboração do Quadro Europeu Comum de Referência (QERC), com vistas a fornecer uma base comum para a elaboração de programas de línguas, linhas de orientação curriculares, exames, manuais etc., na Europa.

O QECR (CONSELHO DA EUROPA, 2001) inclui a descrição de qualificações necessárias para a aprendizagem de línguas e visa a promover o plurilinguismo, isto é, colaborar com a difusão de uma maior variedade de línguas europeias. Entre as utilizações previstas desse documento orientador, encontram-se declaradas: fornecer uma base comum para a elaboração de programas de línguas, linhas de orientação curriculares, exames, manuais, etc., na Europa; promover e facilitar a cooperação entre instituições de ensino de diferentes países; construir uma base sólida para o reconhecimento mútuo das qualificações em línguas; ajudar aprendentes, professores, organizadores de cursos, júris de exame e responsáveis pelo ensino a enquadrar e coordenar os seus esforços etc.

Observa-se, assim, que esse documento, ao discriminar as várias dimensões consideradas prioritárias na descrição da proficiência em línguas, disponibiliza uma série de pontos de referência (níveis ou patamares) que permite calibrar o progresso na aprendizagem em várias línguas faladas na Europa, por isso também serve de base para a elaboração do Quadro de Referência para o Ensino de Português no Estrangeiro (QuaREPE). 
No âmbito da América do Sul, embora na assinatura do Tratado de Assunção, firmado entre Argentina, Brasil, Paraguai, Uruguai, em 1991, estivesse previsto o estabelecimento de políticas de Estado em relação às línguas oficiais da América do Sul (espanhol, português brasileiro e guarani), o que poderia ter motivado a elaboração de um documento similar ao QECR, isso não aconteceu. Assim, muitos programas de cursos e de livros didáticos, bem como e os exames de proficiência em línguas têm no documento europeu a principal referência teórico-prática. Trata-se de uma assunção, muitas vezes acrítica, sem diálogo intercultural, cabendo àqueles localizados na "periferia" cultural o papel de acatar decisões tomadas para atender aos interesses europeus.

No âmbito nacional, cinco grupos de documentos nacionais têm orientado a organização dos cursos e o desenvolvimento de materiais didáticos para o português como língua adicional:

1) os Parâmetros Curriculares Nacionais de Língua Estrangeira, em dois volumes, um destinado ao ensino fundamental e outro ao médio, sendo que este último ainda contou com um desdobramento conhecido, como PCN+ Ensino Médio (BRASIL, 1998, 2000, 2002);

2) Ensino de língua portuguesa para surdos: caminhos para a prática pedagógica (SALLES et al., 2004);

3) Orientações Curriculares para o Ensino Médio (BRASIL, 2006);

4) Base Nacional Comum Curricular (BRASIL, 2017), voltada ao ensino fundamental, e a versão destinada ao ensino médio (BRASIL, 2018);

5) Editais publicados pelo Programa Nacional do Livro Didático (PNLD).

A análise dos documentos oficiais associada a um processo de cotejamento da arquitetura por meio da qual o Estado brasileiro organizou a sua política linguística na esfera constitucional evidencia os motivos pelos quais as minorias linguísticas brasileiras, oriundas de processos migratórios ocorridos no final do século XIX e início do XX, não são contempladas nos currículos escolares da Educação Básica. O fato é que essas línguas não receberam os devidos estatutos jurídicos constitucionais, o que acarreta, desse modo, ao menos legislativamente e em matéria de Educação, o fato de que essas línguas não existem para o Estado (ABREU, 2019).

Um dos poucos dispositivos normativos que contemplavam, ainda que indiretamente, as línguas das minorias linguísticas oriundas de processos de imigração estava disposto na primeira versão da Lei 9.394/96, Lei de Diretrizes e Bases (LDB), que, no seu § 5ㅇ, Art. 26, fundamentando-se no princípio da gestão democrática da educação, dispunha que "Na parte diversificada do currículo será incluído, obrigatoriamente, a partir da quinta série, o ensino de pelo menos uma língua estrangeira moderna, cuja escolha ficará a cargo da comunidade escolar, dentro das possibilidades da instituição" (BRASIL, 1996). Esse paradigma, no entanto, foi alterado pelas leis 11.161/2005 e 13.415/2017, que determinaram as ofertas obrigatórias da língua espanhola e a língua inglesa, respectivamente, em etapas específicas da educação básica. 
Essa mudança paradigmática na LDB no que diz respeito ao ensino de língua estrangeira teve como um dos seus efeitos colaterais o fechamento de uma das poucas possibilidades de oferta regular das línguas brasileiras de imigração nas escolas das comunidades falantes de tais línguas.

As formas por meios das quais os Estados organizam as suas legislações, sobretudo aquelas que constituem seus sistemas educacionais, se configuram como fator decisivo para que comunidades minoritárias inteiras possam exercer, de modo pleno ou parcial, o direito à escolarização em suas línguas maternas (GERALDI, 2009). Esse direito, componente central nos ambientes nos quais se pretende disseminar ideia de cidadania linguística, quando negado, por ação ou omissão estatal, corrói a base de qualquer projeto de educação para a cidadania global, pois usurpa das crianças, adolescentes, jovens e adultos a possibilidade de convívio em ambientes nos quais a interculturalidade e o respeito à diversidade possam ser vivenciados na prática, colocando em situações de protagonismo grupos que são sistematicamente sub-representados ou até mesmo, em alguns casos, marginalizados (BATORÉO, 2009; NZAU; SARDINHA, 2009).

\section{Cidadania e imagem do brasileiro em livros didáticos}

Os processos de ensino-aprendizagem de línguas - materna e estrangeria - são organizados a partir dos documentos norteadores, o que, muitas vezes, é "[...] fortemente influenciado pelo livro didático (doravante LD) [...]" (DINIZ, STRADIOTTI, SCARAMUCCI, 2009). Assim, para identificar o tipo de trabalho que tem sido realizado no âmbito do ensino de línguas adicionais, requer observar o que tem sido selecionado para compor as atividades e os exercícios, uma vez que ao adotar um LD, o professor acaba por incluir em suas práticas docentes a visão do outro, ou seja, dos especialistas e/ou profissionais que compuseram as obras adotadas, tornando-o mais um integrante da relação pedagógica (PIRIS; AZEVEDO, 2018).

Gonçalves e Azevedo (2020), ao investigar como as imagens acerca da cultura brasileira são representadas no livro didático Bem-vindo!, edição de 2009, observaram que os elementos selecionados pelos autores produzem uma visão idealizada do Brasil, o que colabora com o reforço de estereótipos em circulação no mundo e até mesmo dentro do próprio país e dificulta haver espaço para rupturas que poderiam favorecer a produção de novos sentidos. Diante disso, neste artigo, optou-se por analisar duas obras que declaram estar desenvolvidas na perspectiva intercultural.

Ver-se-á ainda como o LD de português brasileiro como adicional se comporta quanto à estereotipia e ao desenvolvimento da noção de cidadania global, em dois cenários de produção diferentes, no LD Estação Brasil: Português para Estrangeiros (BIZON, PATROCínIO, 2017) e no LD Brasil Intercultural - Língua e Cultura Brasileira para Estrangeiros (MOREIRA, BARBOSA, CASTRO, 2014). Ambos os LDs declaram trabalhar alinhados a uma perspectiva intercultural, sendo que o primeiro é produzido no Brasil e o segundo na Argentina. 
Na Apresentação da primeira obra, organizada em volume único, Bizon e Patrocínio (2017, p. 5-6) declaram que o LD tem como objetivo "[...] sensibilizar o aprendiz para a complexidade da questão e enriquecer a discussão sobre as atitudes diante das atitudes diante das diferenças culturais" [...], por isso o livro está dividido em quatro linhas temáticas: 1. questões culturais; 2 . cidadania e cotidiano; 3 . trabalho e qualidade de vida; 4 . Linguagens. Como as autoras atuam na área acadêmica e educacional há mais de trinta anos, as atividades reúnem práticas já realizadas em cursos de formação em diferentes níveis e visam à superação do nível intermediário.

A segunda obra foi desenvolvida a pedido da Casa do Brasil (um Centro Cultural localizado em Buenos Aires, na Argentina), visando ao ensino específico do português brasileiro na perspectiva da interculturalidade. Está dividida em seis níveis, organizados em quatro volumes (ciclo básico, ciclo intermediário, ciclo avançado e ciclo de aperfeiçoamento) e tem o foco específico de voltar-se a falantes de língua espanhola. Segundo os autores, na Apresentação, a coleção permite "[...] conhecer e viver a língua-cultura brasileira, considerando as suas características e a sua relação com as outras culturas que, conjuntamente, conformam a(s) identidade(s) latino-americana(s)" (MOREIRA, BARBOSA, CASTRO, 2014, p. 1).

Quadro 2 - Destaque quanto ao olhar para a estereotipia

\begin{tabular}{|c|c|}
\hline \multicolumn{2}{|l|}{ BIZON, PATROCÍNIO, 2017} \\
\hline Presença/ausência de estereotipias & Referências para a cidadania global \\
\hline $\begin{array}{l}\text { A atenção às mudanças observadas nas dinâmicas sociais no que diz } \\
\text { respeito a situações de preconceito que podem ser identificadas na } \\
\text { sociedade brasileira, diferenças em relação ao papel da mulher, juízos } \\
\text { de valor em relação às diferentes carreiras profissionais são pontos } \\
\text { privilegiados que permitem discutir como alguns comportamentos } \\
\text { linguísticos podem gerar os estereótipos negativos. A diversidade de } \\
\text { situações recolhidas é outro ponto positivo, mas não há uma } \\
\text { associação entre as desigualdades sociais e linguísticas. }\end{array}$ & $\begin{array}{l}\text { Não há menção com relação ao } \\
\text { fortalecimento político da língua } \\
\text { portuguesa mundo afora, nem } \\
\text { mesmo à sua representatividade no } \\
\text { plano internacional, também não há } \\
\text { atenção ao sentimento de } \\
\text { pertencimento a uma comunidade } \\
\text { mais ampla à humanidade. }\end{array}$ \\
\hline \multicolumn{2}{|l|}{ MOREIRA, BARBOSA, CASTRO, 2014} \\
\hline Presença/ausência de ester & Referências para a cidadania global \\
\hline $\begin{array}{l}\text { Embora a obra proponha partir da cultura-nativa para compreender } \\
\text { que as diferenças em relação à cultura decorrem de interações sociais } \\
\text { e históricas e recolha textos que circulam na sociedade brasileira, as } \\
\text { situações comunicativas selecionadas são tão artificiais quanto às } \\
\text { atividades encontradas tradicionalmente em outros livros didáticos e } \\
\text { há o reforço de um estereótipo unificado de brasileiro como povo } \\
\text { feliz, que gosta de samba e festas, sem marcação das distinções } \\
\text { relativas às características dos variados grupos sociais que } \\
\text { historicamente constituem a população brasileira. Além disso, os } \\
\text { exercícios não favorecem uma reflexão crítica acerca dos contrastes } \\
\text { sociais identificados nos dois países, pois o principal objetivo ainda é } \\
\text { compreender a língua como um objeto único, sem contrastes. }\end{array}$ & $\begin{array}{l}\text { Alguns temas poderiam ser } \\
\text { ampliados no sentido dos diretos } \\
\text { linguísticos construídos ao longo da } \\
\text { história, mas isso não é realizado. } \\
\text { Também não há menção aos modos } \\
\text { de materialização da cidadania } \\
\text { global, nem mesmo a citação relativa } \\
\text { às ações mitigantes observadas na } \\
\text { sociedade brasileira. }\end{array}$ \\
\hline
\end{tabular}

Fonte: Elaboração dos autores. 
Registram-se no quadro 2 a inexistência de menção em relação ao fortalecimento político da língua portuguesa mundo afora e do seu grau de representatividade no plano internacional, aliada a uma omissão no que diz respeito a um sentimento de pertencimento a uma comunidade mais ampla e global. Também deixou de ser contemplada uma atitude apoiada por um entendimento de múltiplos níveis de identidade e ainda não se vêm demarcados esforços no sentido de desenvolver a construção de uma identidade coletiva que transcenda diferenças individuais culturais, religiosas, éticas ou outras (como o sentimento de pertencer a uma humanidade comum e o respeito pela diversidade).

Ao consultar ambas as obras, observa-se que há um apagamento das minorias étnicas constitutivas da nação brasileira e estão ausentes as especificidades das variantes linguísticas, como destacado no quadro 2. Particularmente, no LD produzido no Brasil, é possível notar a sensibilidade de retratar uma variedade de situações que refletem as mudanças da sociedade brasileira nos últimos anos, mas essa observação não é articulada aos impactos produzidos no uso da língua portuguesa de variante brasileira, considerando toda sua diversidade, como propõe o ensino voltado para a cidadania global.

A título de ilustração, propõe-se aqui o exame de um excerto da obra (Imagem 2).de uma das obras supracitadas.

Figura 2 - Fragmento da Plataforma 1: Construções culturais

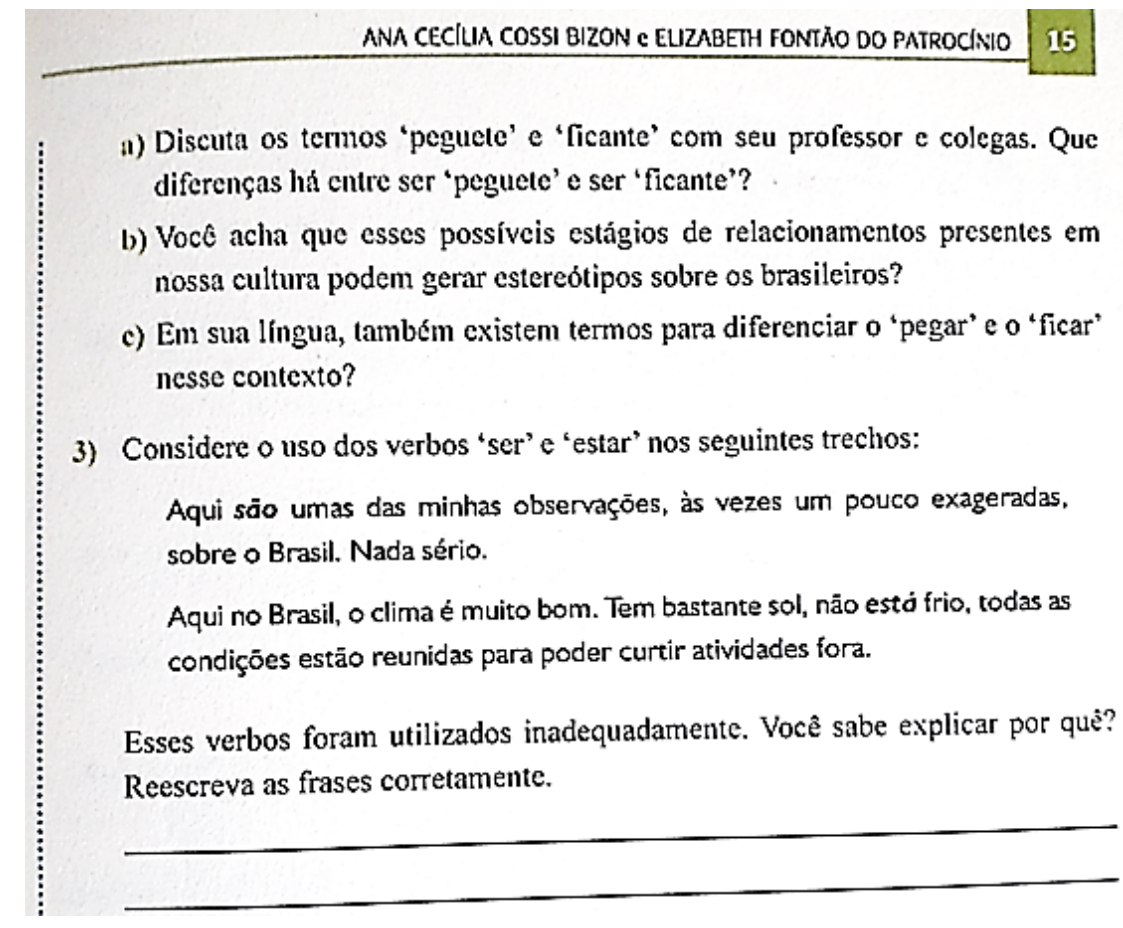

Fonte: Bizon e Patrocínio (2017, p. 15).

A menção às expressões que remetem a dois tipos de relacionamento íntimo demarca a existência de diversidade nas interações e, ao mesmo tempo, de estereótipos quanto às formas de nomeação deles na sociedade brasileira, pois ressaltam apenas alguns aspectos da 
dimensão cultural a partir dos tópicos recolhidos para compor o LD. As consignas, por sua vez, que orientam o trabalho em sala estão limitadas à troca de opiniões acerca das experiências vividas, não remetendo às diferenças de classe social, de faixa etária, de proximidade entre os interlocutores, entre outras questões culturais, que são consideradas quando se quer possibilitar a convivência cidadã (GIMÉNEZ ROMERO, 2010).

Assim, para haver desenvolvimento da consciência crítica intercultural, o processo de ensino-aprendizagem tem no LD uma referência limitada que requer a inclusão de inúmeras outras práticas de linguagem direcionadas à ampliação das discussões. Em relação às possibilidades de uso do português na variedade brasileira, a obra é ainda mais restrita uma vez que apenas identifica verbos "utilizados inadequadamente" e solicita reescritas corretas. A atividade deixa de levar em consideração aspectos funcionais e pragmáticos que permitiriam a plena compreensão da sentença "Aqui no Brasil, o clima é muito bom. Tem bastante sol, não está frio, [...]", circunscrevendo a análise linguística a aspectos normativos.

A obra produzida na Argentina (MOREIRA; BARBOSA; CASTRO, 2014), por sua vez, apresenta situações comunicativas que remetem a uma das razões possíveis para se aprender uma língua estrangeira (o interesse por viajar e descobrir o mundo) e parte de um texto de opinião em circulação na sociedade brasileira, mas as questões de interpretação insistem em apenas recuperar as experiências pessoais:

1. De acordo com o texto, por que viajar pode ser uma experiência inesquecível?

2. De que maneira conhecer o mundo para Grace e Rob também representou abandonar preconceitos e conhecer mais sobre si mesmos?

3. Você concorda que viajar acaba sendo uma experiência mais ampla do que conhecer novos lugares? Por quê? (MOREIRA; BARBOSA; CASTRO, 2014, p. 53)

Nota-se que o texto selecionado ("Viajar é preciso", de Juliana Araújo, retirado da revista Sorria, em 2012) e as questões exploram as viagens que permitem acumular experiências diferenciadas de acordo com os costumes de cada lugar, como Estados Unidos, Canadá, Índia. Apesar disso, o texto que destaca o encanto por participar de um safári africano em nenhum momento apontou os contrastes sociais que se encontram nesses países, e as consignas também não possibilitaram ampliar as reflexões restritas ao âmbito pessoal. Além das três questões transcritas anteriormente, encontram-se na unidade atividades variadas, como: relacionar palavras e expressões utilizadas no Brasil, perceber sons nasais, conhecer a conjugação de verbos regulares no pretérito do indicativo, completar letras de música apresentadas com lacunas, ler descrições de lugares turísticos brasileiros etc. Assim, a dimensão cultural que se observa nas atividades está apoiada na indicação de lugares, e circunstâncias típicas de certas regiões mais valorizadas enquanto pontos turísticos e não há menção aos variados grupos sociais que convivem em um mesmo espaço social, o que poderia favorecer a reflexão em torno da cidadania global. Em relação aos usos da língua, o LD apenas aponta a existência variadas expressões para uma mesma circunstância. Isso indica que caberá ao professor o esforço de complementar o material no sentido de motivar o desenvolvimento de uma cidadania linguística. 
Essa breve ilustração aponta que a produção do material didático para o ensino de português como língua adicional voltado para uma formação para a cidadania global requer o conhecimento mais detalhado da realidade social local, sob pena de promover a reprodução das estereotipias e reforço do preconceito ao brasileiro. 0 mito da homogeneidade linguística do português brasileiro, também presente nos LD de ensino de língua materna, inclusive os selecionados pelo PNLD (COAN; FREITAG, 2010), se reproduz nos LD de português brasileiro como língua adicional. Isso ainda ocorre, apesar de todos os esforços na direção de uma formação linguística voltada para a cidadania global defendida em documentos internacionais, reforçando a emergência da formação sociolinguística do professor de português, tanto de língua materna quanto de língua adicional, da formação em direitos humanos e em torno de temas associados à cidadania global.

\section{Considerações finais}

Ao retomar o conceito de cidadania global, procurou-se ressaltar neste artigo algumas materializações do projeto de cidadania linguística, com base na variedade brasileira do português que serve de referência para o português como língua adicional, a fim de compreender o papel das representações sociais/simbólicas e da estereotipia na constituição desse tipo de projeto. Para tanto, foram tematizados alguns aspectos localizados em dois livros didáticos, declaradamente alinhados à perspectiva intercultural, e foi observado que, apesar de se apresentarem preocupados com aspectos característicos da sociedade brasileira, ainda dissociam a estrutura da língua da sua dimensão cultural. Embora essa não seja uma exclusividade dos livros voltados para o ensino de português como língua adicional, pois são encontrados problemas similares em materiais voltados ao ensino de português como língua materna no Brasil, procurou-se marcar como a representação das variedades do português brasileiro se faz pouco presente nos livros didáticos, apesar de todos os avanços descritivos da sociolinguística e de algumas políticas linguísticas dos últimos 20 anos.

As dificuldades na superação de uma visão restrita, registrada nos livros que apoiam o trabalho do professor tanto de língua materna quanto de língua adicional, são agravadas pelo fomento limitado a um conhecimento menos estereotipado de outras culturas e pela reflexão limitada ao destaque de experiências pessoais acerca da cultura do outro em comparação com a própria. Esta limitação tolhe o engajamento com as realidades locais, regionais, nacionais e globais, um dos eixos norteadores da educação para a cidadania global, o que impacta na concretização do direito linguístico, compreendido como um dos direitos fundamentais que coexiste com o da liberdade, o da igualdade e o da dignidade humana.

Assim, defende-se aqui o desenvolvimento de estudos e pesquisas que promovam a consciência crítica para que possa haver o fortalecimento de uma visão que supere a estereotipia limitadora, que ainda se vê representada em livros didáticos, por exemplo, produzidos dentro e fora do país. Esta limitação tolhe o engajamento com as realidades locais, regionais, nacionais e globais, o que impacta na concretização do direito linguístico, como 
apontamos, um dos direitos fundamentais, a exemplo da liberdade, da igualdade e da dignidade humana. Do mesmo modo, o desenvolvimento da consciência crítica é enfraquecido por conta também da estereotipia, sendo esta mais presente nos materiais didáticos produzidos fora do país, possivelmente por conta da distância da realidade sociocultural, do cotidiano brasileiro.

Estes aspectos negativos evidenciados na análise empreendida são decorrentes da ausência de políticas linguísticas para o ensino de português como língua adicional que considerem o Brasil como referência, restringindo a materialização de um projeto de cidadania linguística. A fim de superar estas barreiras, destaca-se a importância da inserção nos programas de ensino das contribuições de estudos descritivos de natureza sociolinguística do português brasileiros para a identificação de valores identitários regionais a traços linguísticos variáveis e como estes se manifestam nas representações regionais, uma forma de desfazer o mito do monolinguismo, e favorecendo um ensino dissociado da construção de estereótipos culturais, especialmente em relação ao Brasil. Do mesmo modo, destaca-se a importância da formação de professores para lidar com a realidade multilíngue e diversificada dialetalmente na construção da cidadania global, com diretrizes comuns.

Assim, com este trabalho, intentou-se marcar os pontos que podem fomentar ações direcionadas a promover a reflexão em torno do papel que o português brasileiro, como língua adicional, pode ter como protagonista no desenvolvimento da cidadania global dentro e fora do país.

\section{Referências}

ABREU, R. N. Estatutos jurídicos e processos de nacionalização de línguas no Brasil. Revista da ABRALIN, v. 17, n. 2, p. 46-76, 2019. https://doi.org/10.25189/rabralin.v17i2.1324

ABREU, R. N. Os direitos linguísticos: possibilidades de tratamento da realidade plurilíngue nacional a partir da constituição da República Federativa do Brasil de 1988. 2016. 115 f. Dissertação de Mestrado. Programa de Pós-Graduação em Direito da Universidade Federal de Sergipe. São Cristóvão: Universidade Federal de Sergipe, 2016.

ALFAIATE, A. C. P. O diálogo intercultural através da arte na aula de PLNM: a azulejaria portuguesa no ensino de português a estrangeiros. 2018. 84 f. Dissertação de Mestrado em Português Língua não Materna apresentada à Universidade Aberta. Nairóbi: [s.n.], 2018.

ANDRADE, A. I.; MARTINS, F. Educação global e diversidade linguística na formação inicial de educadores e professores: da intervenção à (auto) reflexão. Indagatio Didactica, v. 10, n. 1, p. 47-62, 2018.

ANJOS FILHO, R. N. Direito ao desenvolvimento. São Paulo: Saraiva, 2013.

BARROS, M. C., BORGES, L.; MEIRA, M. A Língua Geral Como Identidade Construída. Revista de Antropologia, v. 1, n. 39, p. 191-219, 1996. 
BATORÉO, H. J. A(s) minha(s) língua(s): Bilinguismo e o direito à diversidade linguística. In: PINTO, P. F.; BROHY, C.; TÜRI, J.-G. (org.). Direito, Língua e Cidadania Global. Lisboa: Associação de Professores de Português, 2009. p. 141-148.

BIZON, A. C. C.; PATROCÍNIO, E. F. Estação Brasil - Português para Estrangeiros. 2. ed. Campinas: Editora Átomo, 2017.

BOURDIEU, P. A economia das trocas linguísticas: o que falar quer dizer. São Paulo: Edusp, 2008.

BRASIL. Lei 11.161. Altera as Leis $\mathrm{n} \cong 9.394$, de 20 de dezembro de 1996, que estabelece as diretrizes e bases da educação nacional, e 11.494, de 20 de junho 2007, que regulamenta o Fundo de Manutenção e Desenvolvimento da Educação Básica e de Valorização dos Profissionais da Educação, a Consolidação das Leis do Trabalho - CLT, aprovada pelo DecretoLei no 5.452, de 10 de maio de 1943, e o Decreto-Lei no 236, de 28 de fevereiro de 1967; revoga a Lei no 11.161, de 5 de agosto de 2005; e institui a Política de Fomento à Implementação de Escolas de Ensino Médio em Tempo Integral. Brasília, DF, 2017.

BRASIL. Lei 11.161. Dispõe sobre o ensino de língua espanhola. Brasília, DF, 2005.

BRASIL. Lei 9.394. Estabelece as diretrizes e bases da educação nacional. Brasília, DF, 1996.

BRASIL. Ministério da Educação, Secretaria de Educação Básica. Base Nacional Comum Curricular. Brasília, DF: MEC, 2017.

BRASIL. Ministério da Educação, Secretaria de Educação Básica. Base Nacional Comum Curricular - Ensino Médio. Brasília, DF: MEC, 2018.

BRASIL. Ministério da Educação, Secretaria de Educação Básica. Orientações Curriculares para o Ensino Médio: linguagens, códigos e suas tecnologias. Brasília, DF: SEB/MEC, 2006.

BRASIL. Ministério da Educação, Secretaria de Educação Fundamental. Parâmetros Curriculares Nacionais de Língua Estrangeira: 3으 e 4을 ciclos do Ensino Fundamental - Língua Estrangeira. Brasília: MEC, 1998.

BRASIL. Ministério da Educação, Secretaria de Educação Média e Tecnológica. Parâmetros Curriculares Nacionais: Ensino Médio. Brasília, DF: MEC, 2000.

BRASIL. Ministério da Educação, Secretaria de Educação Média e Tecnológica. PCN + Ensino Médio: Orientações Educacionais Complementares aos Parâmetros Curriculares Nacionais. Linguagens, Códigos e suas Tecnologias. Brasília, DF: MEC, 2002.

COAN, M.; FREITAG, R. M. K. Sociolinguística variacionista: pressupostos teóricometodológicos e propostas de ensino. Domínios de Lingu@gem, v. 4, n. 2, p. 173-194, 2010.

CONSELHO DA EUROPA. Quadro Europeu Comum de Referência para as Línguas aprendizagem, ensino, avaliação. Tradução de Maria Joana Pimentel do Rosário e Nuno Verdial Soares. Porto: Edições Asa: 2001.

DINIZ, L. R. A.; STRADIOTTI, L. M.; SCARAMUCCI, M. V. R. Uma análise de livros didáticos de português para estrangeiros. In: DIAS, R.; CRISTÓVÃO, V. L. O livro didático de língua estrangeira: múltiplas perspectivas. Campinas: Mercado de Letras, 2009. p. 265-304.

COSTA, E. J.; SILVA, F. C. O potencial de Minas Gerais no desenvolvimento da competência intercultural dos alunos de PLAC. Revista Recorte, v. 16, n. 2, 2019. 
DAVIES, L. Global citizenship: abstraction or framework for action? Educational review, v. 58, n. 1, p. 5-25, 2006. https://doi.org/10.1080/00131910500352523

DUSELL, E. Transmodernidade e interculturalidade: interpretação a partir da filosofia da libertação. Revista Sociedade e Estado, v. 31, n. 1, p. 51-73, 2016. https://doi.org/10.1590/S0102-69922016000100004

FARACO, C. Norma culta brasileira: desatando alguns nós. São Paulo: Parábola Editorial, 2008.

FERREIRA, R. P.; ANTUNES, A. J. Refletindo sobre as contribuições da Sociolinguística para o ensino de Português como Língua Adicional (PLA). BELT-Brazilian English Language Teaching Journal, v. 9, n. 2, p. 308-322, 2018. https://doi.org/10.15448/2178-3640.2018.2.31561

FILIPE, M. Cidadania Europeia e Direitos Linguísticos no espaço da União. In: PINTO, P. F.; BROHY, C.; TÜRI, J.-G. (org.). Direito, Língua e Cidadania Global. Lisboa: Associação de Professores de Português, 2009. p. 474-480.

FINARDI, K. R.; GUIMARÃES, F. F. Construindo Cidadania Por Meio da Língua e da Internacionalização. Revista Guará, v. 5, n. 8, p. 35-46, 2017. https://doi.org/10.30712/guara.v5i8.15324

FREITAG, R. M. K. Sociolinguística no/do Brasil. Cadernos de Estudos Linguísticos, v. 58, n. 3, p. 445-460, 2016. https://doi.org/10.20396/cel.v58i3.8647170

FREITAG, R. M. K. et al. Como o brasileiro acha que fala? Desafios e propostas para a caracterização do" português brasileiro". Signo y seña, n. 28, p. 65-87, 2015.

FREITAG, R. M. K. et al. Como os brasileiros acham que falam? Percepções sociolinguísticas de universitários do Sul e do Nordeste. Todas as Letras-Revista de Língua e Literatura, v. 18, n. 2, p. 64-84, 2016. https://doi.org/10.15529/1980-6914/letras.v18n2p64-84

FREITAG, R. M. K. et al. O uso da língua para a discriminação. A Cor das Letras, v. 21, n. 1, p. 185-207, 2020. https://doi.org/10.13102/cl.v21i1.5233

GERALDI, J. W. Da liberdade ao direito à expressão: hegemonias e subalternidades. In: PINTO, P. F.; BROHY, C.; TÜRI, J.-G. (org.). Direito, Língua e Cidadania Global. Lisboa: Associação de Professores de Português, 2009. p. 65-77.

GIMÉNEZ ROMERO, C. Interculturalidade e Mediação Trad. A. Gouveia. Lisboa: Alto Comissariado para a Imigração e Diálogo Intercultural (ACIDI, IP), 2010. Disponível em: http://resmi.isinapse.com/images/publicacoes/Caderno 4.pdf. Acesso em: 21 ago. 2020.

GIORDAN, H.; AGRESTI, G. Connaître et promouvoir la diversité: le projet LEM (Langues de Europe et de la Méditerranée) et les droits linguistiques. In: PINTO, P. F.; BROHY, C.; TÜRI, J.G. (org.). Direito, Língua e Cidadania Global. Lisboa: Associação de Professores de Português. 2009. p. 337-346.

GONÇALVES, R.; AZEVEDO, I. C. M. O papel dos estereótipos na construção da identidade dos brasileiros em um livro didático de PLE. In: LIMA, M. E. O.; FRANÇA, D. X.; FREITAG, R. M. K. Processospsicossociais de exclusão social. São Paulo: Editora Blucher Open Access, 2020. p. 73-88. https://doi.org/10.5151/9786555060393-03

HAMILTON, D. L.; TROLIER, T. K. Stereotypes and stereotyping: An overview of the cognitive approach. In: DOVIDIO, J. L.; GAERTNER, S. L. (Eds.), Prejudice, discrimination, and racism. New York: Academic Press, 1986. p. 127-163. 
HOBSBAWM, E. Introdução. In: HOBSBAWM, E.; RANGER, T. (orgs.). A invenção das tradições. Rio de Janeiro: Paz e Terra, 1984. p. 19-23.

HONNETH, A. Luta por reconhecimento: a gramática moral dos conflitos sociais. São Paulo: Editora 34, 2011.

JESUS, M. P. Cidadania global: uma construção cultural e linguística. C@LEA-Revista Cadernos de Aulas do LEA, n. 5, p. 43-52, 2016.

ISIN, E. F. Citizenship in Flux: the Figure of the Activist Citizen. Subjectivity, v. 29, p. 367-388, 2009. https://doi.org/10.1057/sub.2009.25

JUDD, E. L.; TAN, L.; WALBERG, H. J. Teaching additional languages. Genebra: International Academy of Education/International Bureau of Education, 2001.

KRAMSCH, C. Cultura no ensino de língua estrangeira. Trad. Orison Marden Bandeira de Melo Júnior. Bakhtiniana: Revista de Estudos do Discurso, v. 12, n. 3, p. 134-152, 2017. https://doi.org/10.1590/2176-457333606

LUCCHESI, D. Parâmetros sociolinguísticos do português brasileiro. Revista da ABRALIN, v. 5, n. 1/2, p. 83-112, 2017. https://doi.org/10.5380/rabl.v5i1/2.52637

MANOLE, V. Uma língua, várias culturas: algumas reflexões sobre os aspectos sociolinguísticos na localização em português brasileiro e em português europeu. Revue Internationale d'Études en Langues Modernes Appliquées, v. 6, n. Suppl., p. 53-63, 2013.

MARTINS, M. L. A lusofonia no contexto das identidades transnacionais e transcontinentais. Letrônica, v. 11, n. 1, p. 3-11, 2018. https://doi.org/10.15448/19844301.2018.1.30438

MARTINS, M. L. Globalization and lusophone world. Implications for citizenship. In: PINTO, M.; SOUSA, H. (Org.). Communication and Citizenship: Rethinking crisis and change. Coimbra: Grácio Editor, 2011. p. 75-84.

MIYAMOTO, S. O Brasil e a comunidade dos países de língua portuguesa (CPLP). Revista Brasileira de Política Internacional, v. 52, n. 2, p. 22-42, 2009. https://doi.org/10.1590/S0034$\underline{73292009000200002}$

MOREIRA, A.; BARBOSA, C. N.; CASTRO, G. N. Brasil Intercultural - Língua e cultura brasileira para estrangeiros. Ciclo Básico - Níveis 1 e 2. Buenos Aires: Casa do Brasil, 2014.

NZAU, D.; SARDINHA, M. da G. Multilinguismo e direitos linguísticos: o direito à diversidade linguística (O caso de Angola). In: PINTO, P. F.; BROHY, C.; TÜRI, J.-G. (org.). Direito, Língua e Cidadania Global. Lisboa: Associação de Professores de Português. 2009. p. 209-223.

O GLOBO, Itamaraty tira do ar apostila para estrangeiros com frase preconceituosa e citações ao aborto e ao MST. O Globo, 15 de julho de 2020. Disponível em https://oglobo.globo.com/brasil/itamaraty-tira-do-ar-apostila-para-estrangeiros-com-frasepreconceituosa-citacoes-ao-aborto-ao-mst-24532823. Acesso em: 31 jul. 2020.

OLIVEIRA, G. M. Política linguística e internacionalização: a língua portuguesa no mundo globalizado do século XXI. Trabalhos em linguística aplicada, v. 52, n. 2, p. 409-433, 2013. https://doi.org/10.1590/S0103-18132013000200010 
OTUKI de PONCE, M.; ANDRADE BURIM, S.; FLORISSI, S. Bem-vindo! A língua portuguesa no mundo da comunicação: português para estrangeiros. 4. ed. São Paulo: SBS, 2009

PINSKY, J.; PINSKY, C. B. História da cidadania. São Paulo: Contexto, 2012.

PIOVESAN, F.; SOARES, I. V. Direito ao Desenvolvimento. Belo Horizonte: Fórum, 2010.

PIRIS, E. L.; AZEVEDO, I. C. M. de. Subjetivação, saberes e poderes: o autor do livro didático como um interveniente na relação pedagógica. In: AQUINO, Z. G. O., et al. (Org.). Estudos do discurso: o poder do discurso e o discurso do poder. São Paulo: Editora Paulistana, 2018. v. 1. p. $122-143$.

PONSO, L. C. O português no contexto multilíngue de Angola. Confluência, v. 35, n. 36, p. 147162, 2008.

PREUSS, E. O.; ALVARES, M. R. Bilinguismo e políticas linguísticas no Brasil: da ilusão monolíngue a realidade plurilíngue. Acta Scientiarum. Language and Culture, v. 36, n. 4, p. 403-415, 2014. https://doi.org/10.4025/actascilangcult.v36i4.23169

RONCARATI, C.; SILVA, D. B.; PONSO, L. C. Um olhar crítico sobre a sociometria da língua $\begin{array}{lllllll}\text { portuguesa. Gragoatá, } & \text { v. } \quad 17, \quad \text { n. } & 32, & \text { p. } & 75- & 98,\end{array}$ https://doi.org/10.22409/gragoata.2012n32a33033

RUSSELL, J.; COHN, R. Linguistic rights. Edinburgh: Lennex Corp., 2012.

SALLES, H. M. M. L. et al. Ensino de língua portuguesa para surdos: caminhos para a prática pedagógica. Brasília: MEC, SEESP, 2004. v. 2.

SANTOS, B. S.; MENESES, M. P. Epistemologias do Sul. São Paulo: Cortez, 2010.

SCHLATTER, M.; GARCEZ, P. de M (org.). Multilingual Brazil: Language Resources, Identities and Ideologies in a Globalized World. New York, NY: Routledge, 2018. https://doi.org/10.4324/9781315623870-18

SANTOS, D. Portuguese language identity in the world: adventures and misadventures of an international language. In: KHACHATURYAN, E. (ed.). Additional Language-Nation-Identity: The questione della lingua in an Italian and non-Italian context. Cambridge: Cambridge Scholars Publishing, 2015. p. 29-48.

SANTOS, G. F. Língua oficial e direitos linguísticos na Constituição Brasileira de 1988. In: PINTO, P. F.; BROHY, C.; TÜRI, J.-G. (org.). Direito, Língua e Cidadania Global. Lisboa: Associação de Professores de Português, 2009. p. 254-268.

SANTOS, L. C.; FROSSARD, E. C. M. A capacidade multilíngue e seu perfil multicultural na promoção da cidadania global. C@LEA - Revista Cadernos de Aulas do LEA, n. 7, p. 110-131, 2018.

SEN, A. Desenvolvimento como liberdade. São Paulo: Companhia das Letras, 2010.

SEQUEIRA, R. M. Da consciência crítica intercultural e educação para a cidadania global. Revista Boletín Redipe, v. 7, n. 7, p. 129-136, 2018.

SHULTZ, L. Educating for global citizenship: Conflicting agendas and understandings. Alberta Journal of Educational Research, v. 53, n. 3, p. 248-258, 2007. 
SIGALES-GONÇALVES, J. S. Direitos linguísticos no acesso ao direito à educação por migrantes forçados no Brasil: Estado, práticas e educação superior. 2018. 173 f. Dissertação (mestrado em Direito). Programa de Pós-Graduação em Direito da Faculdade de Direito da Universidade Federal de Pelotas. Pelotas: UFPEL, 2018.

SIPLE. Sociedade Internacional de Português-Língua Estrangeira. Nota de esclarecimento. Natal, 20 jul. 2020.

SPOLSKY, B. Language policy. Cambridge University Press, 2004.

STROUD, Christopher. African Mother-tongue Programmes and the Politics of Language: Linguistic Citizenship Versus Linguistic Human Rights. Journal of Multilingual and Multicultural Development, v. 22, n. 4, p. 339-355, 2001. https://doi.org/10.1080/01434630108666440

TAJFEL, H. Human groups and social categories: Studies in social psychology. Cup Archive, 1981.

TAYLOR, C. Multiculturalismo: examinando a política de reconhecimento. Lisboa: Instituto Piaget, 1994. https://doi.org/10.2307/j.ctt7snkj

TIMBANE, A. A.; BERNARDO, E. P. J. Por uma política linguística nos serviços de saúde: um estudo sociolinguístico do Hospital Regional de Malanje (Angola). Revista Letras Raras, v. 9, n. 2, p. 268-290, 2020. https://doi.org/10.35572/rlr.v9i2.1584

UNESCO. Educação para a cidadania global: preparando alunos para os desafios do século XXI. Brasília: UNESCO, 2015.

UNESCO. Relatório Mundial. Investir na diversidade cultural e no diálogo intercultural, 2009. Disponível em: https://www.comboni.org/app-data/files/allegati/2213.pdf. Acesso em: 10 ago. 2009.

WILLIAMS, Q. E.; STROUD, C. Linguistic citizenship. Language and politics in postnational modernities. Journal of Language and Politics, v. 14, n. 3, p. 406-430, 2015. https://doi.org/10.1075/jlp.14.3.05wil

WOLKMER, A. C.; LEITE, J. R. M. (orgs.). Os "novos" direitos no Brasil. 2. ed. São Paulo: Saraiva, 2012.

Recebido em: 03/08/2020. Aceito em: 23/11/2020. 